\title{
INTERDEPENDENCE BETWEEN THE VOLTAGE-CURRENT RELATION AND THE ENERGY BALANCE FOR THE LINEAR TIME-VARYING INDUCTIVE AND CAPACITIVE ONE-PORTS
}

(Presented by I. Opik)

The energy balance both for the linear inductor with time-varying turns and for the corresponding dual time-varying capacitive one-port is examined and compared with that of the conventional time-varying inductor and capacitor. It is shown that the voltage-current relations for time-varying energy-storing elements depend on the contribution of a parameter changing agent in the energy flow. The corresponding new voltage-current relations that take into account the possibility to vary the equivalent inductance or capacitance by lossless switching without any energy flow from the para. meter changing agent, are derived and discussed.

\section{Introduction}

The behaviour of a linear time-varying inductor with the inductance $L$, current $i_{L}$, voltage $v_{L}$, and a capacitor with the capacitance $C$, current $i_{C}$, voltage $v_{C}$ governed by the classical voltage-current relations

$$
v_{L}=L \frac{d i_{L}}{d t}+i_{L} \frac{d L}{d t}
$$

and

$$
i_{C}=C \frac{d v_{C}}{d t}+v_{C} \frac{d C}{d t}
$$

respectively, have been analysed thoroughly in literature [1-4]. However, as recently shown [5], the relation (1) holds only for the cases characterized by the time-varying permeance $P$ and constant turns $N$, whereas for the case of time-varying turns and invariant permeance it was found

$$
v_{L}=L \frac{d i_{L}}{d t}+\frac{1}{2} i_{L} \frac{d L}{d t}
$$

Nevertheless, there is no contradiction between these two different relations (1) and (3). They merely correspond to the two different possible modes of energy flow for the time-varying inductors. The classical relation (1) corresponds to the energy flow in case of the inductance varying due to the work of the inductance changing agent. On the other hand, the relation (3) is related to the cases characterized by the absence of necessity for work to change the inductance - and, consequently, by the lack of energy flow from the inductance changing agent.

On the basis of the duality principle we can write the dual relation 


$$
i_{C}=C \frac{d v_{C}}{d t}+\frac{1}{2} v_{C} \frac{d C}{d t}
$$

that corresponds to a conceivable linear capacitive one-port dual to the linear inductor with time-varying turns.

Since generally both the permeance $P$ and turns $N$ may vary in time, there must also exist a general voltage-current relation for a linear timevarying inductor, and thus there must be a general dual relation for the conceivable dual capacitive one-port. Hence, another question arises in connection with the realization of a capacitive one-port dual to the linear inductor with time-varying turns.

In this paper general voltage-current relations both for the linear inductor with time-varying turns and for the corresponding dual timevarying capacitive one-port are derived and discussed. A possible realization of such a capacitive one-port using a variable-ratio transformer is examined. The stepped variation of the turns is taken into account.

\section{General voltage-current relation for a linear time-varying inductor}

Let us consider a linear inductor with the turns $N$, permeance $P$, magnetic flux $\Phi$, and flux linkage $\lambda=N \Phi$ connected to an active circuit. The inductance $L$ of the inductor may be expressed in the form

$$
L=P N^{2}=N \Phi / i_{L}
$$

In accordance with (5), the magnetic flux

$$
\Phi=P N i_{L}
$$

Since in the general case both the turns $N$ and permeance $P$ are timevarying, the derivative of the flux

$$
\frac{d \Phi}{d t}=\dot{\Phi}=P N \frac{d i_{L}}{d t}+P i_{L} \frac{d N}{d t}+N i_{L} \frac{d P}{d t}
$$

The voltage across the inductor is given by Faraday's induction law as

$$
v_{L}=N \dot{\Phi}
$$

Therefore, from $(6),(7)$ and $(8)$ we obtain

$$
\begin{gathered}
v_{L}=P N^{2} \frac{d i_{L}}{d t}+P N i_{L} \frac{d N}{d t}+N^{2} i_{L} \frac{d P}{d t}= \\
=L \frac{d i_{L}}{d t}+\Phi \frac{d N}{d t}+i_{L} \frac{d L}{d P} \frac{d P}{d t}= \\
=L \frac{d i_{L}}{d t}+i_{L}\left(\frac{1}{2} \frac{d L}{d N} \frac{d N}{d t}+\frac{d L}{d P} \frac{d P}{d t}\right) .
\end{gathered}
$$

The general voltage-current relation (9) can also be derived from the energy balance for the time-varying inductor, taking into account that the inductor may exchange energy both with the active circuit to which it is connected and with the inductance changing agent. However, it must be kept in mind that the energy of the inductance changing agent is not always involved in changing the inductance - work must be done to change the permeance $P$, but not to change (switch) the turns $N$.

Therefore, the energy delivered by the active circuit to the permeance changing agent from time $t_{0}$ to $t$ is 


$$
\begin{aligned}
W_{P}\left(t_{0}, t\right) & =\int_{t_{0}}^{t} \frac{1}{2} \frac{d L}{d P} \frac{d P}{d t^{\prime}} i_{L}^{2}\left(t^{\prime}\right) d t^{\prime}= \\
& =\frac{1}{2} \int_{t_{0}}^{t} N^{2} \frac{d P}{d t^{\prime}} i_{L}^{2}\left(t^{\prime}\right) d t^{\prime} .
\end{aligned}
$$

At the same time, the energy stored into the magnetic field of the inductor from time $t_{0}$ to $t$ is

$$
E(\Phi(t), t)-E_{0}\left(\Phi\left(t_{0}\right), t_{0}\right)=\left(i_{L}^{2}(t) L(t)-i_{L}^{2}\left(t_{0}\right) L\left(t_{0}\right)\right) / 2 .
$$

Consequently, taking into account both the magnetic field and the permeance changing agent, from (10) and (11), the total energy delivered to the inductor by the active circuit in the time interval from $t_{0}$ to $t$ is

$$
W\left(t_{0}, t\right)=E(\Phi(t), t)-E_{0}\left(\Phi\left(t_{0}\right), t_{0}\right)+W_{P}\left(t_{0}, t\right) .
$$

From (10), (11) and (12), the instantaneous power of the linear timevarying inductor equals

$$
\begin{aligned}
& p_{L}(t)=v_{L}(t) i_{L}(t)=\frac{d W\left(t_{0}, t\right)}{d t}= \\
= & i_{L} L \frac{d i_{L}}{d t}+\frac{1}{2} i_{L}^{2} \frac{d L}{d t}+\frac{1}{2} N^{2} i_{L}^{2} \frac{d P}{d t} .
\end{aligned}
$$

Since from (5)

$$
\frac{d L}{d t}=2 P N \frac{d N}{d t}+N^{2} \frac{d P}{d t}
$$

we get finally from (13) and (14)

$$
p_{L}=i_{L} L \frac{d i_{L}}{d t}+P N i_{L}^{2} \frac{d N}{d t}+N^{2} i_{L}^{2} \frac{d P}{d t},
$$

and

$$
v_{L}=p_{L} / i_{L}=L \frac{d i_{L}}{d t}+P N i_{L} \frac{d N}{d t}-N^{2} i_{L} \frac{d P}{d t},
$$

i.e. an expression identical with (9).

From the general voltage-current relation (9), we can get the voltagecurrent relations (1) and (3) for the two main particular cases characterized by $N=$ const, $P=$ var, and $\cdot N=$ var, $P=$ const, respectively. Indeed, for the case of invariant turns and time-varying permeance from (9), we obtain

$$
v_{L}=P N^{2} \frac{d i_{L}}{d t}+N^{2} i_{L} \frac{d P}{d t}=L \frac{d i_{L}}{d t}+i_{L} \frac{d L}{d t},
$$

i.e. the classical relation (1). The classical case is characterized by changing the inductance only due to the work done by the inductance (permeance) changing agent.

For the recently analyzed case $\left.{ }^{5}\right]$ of time-varying turns and invariant permeance we get from (5),

$$
\frac{d N}{d t}=\frac{d}{d t}(L / P)^{1 / 2}=\frac{1}{2 N P} \frac{d L}{d t}
$$

and now from (9) and (18) 


$$
v_{L}=P N^{2} \frac{d i_{L}}{d t}+P N i_{L} \frac{d N}{d t}=L \frac{d i_{L}}{d t}+\frac{1}{2} i_{L} \frac{d L}{d t}
$$

i.e. the relation (3) that differs from the classical relation (1) only by the additional factor $1 / 2$ in the second term. In this particular case no work is needed to change the inductarice and, consequently, there is no energy flow from the inductance changing agent.

\section{Equivalent circuits}

3.1. Equivalent circuit of the linear inductor with time-varying turns. An ideal linear inductor with time-varying turns may be regarded as a lossless inductive time-varying one-port characterized by a set of straight lines through the origin in the $\lambda i_{L}$ plane, where the flux linkage

$$
\lambda=N \Phi=L i_{L}
$$

It can be conceived that there exists a dual capacitive one-port characterized by the same set of straight lines through the origin in the $q v_{C}$ plane, where the equivalent charge $q$ of the capacitive one-port with the input voltage $v_{C}$ and input capacitance $C$ is defined to be equal

$$
q=C v_{C}
$$

Since in the case of a single capacitor it is difficult to conceive an action analogous to the variation of turns involved in the operation, it will be suitable to replace the ideal inductor by its equivalent circuit containing an ideal variable-ratio transformer, as shown in Fig. 1.

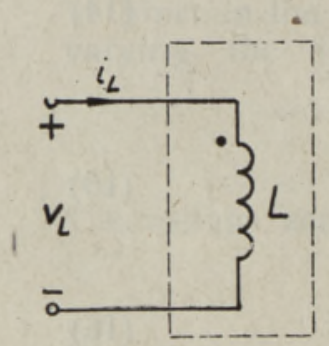

a

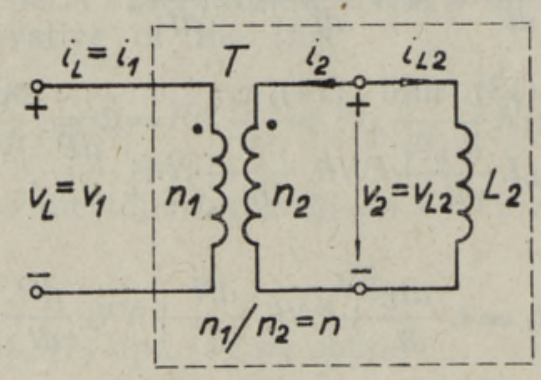

6
Fig. 1. Linear timevarying inductor (a) with inductance $L=$ $=N^{2} P$, and its equivalent circuit $(b)$ using an ideal transformer with turns ratio $n_{1} / n_{2}=n=$ $=N \mathrm{y} / N_{\max } ; L_{2}=N_{\max }^{2} P$.

According to Fig. 1, the linear inductor with time-varying turns $N(t)$ is equivalent, as a one-port, to the parallel connection of the same inductor with the maximal turns $N=N_{\max }=$ const and an ideal transformer with a time-varying turns ratio

$$
n_{1} / n_{2}=n=N(t) / N_{\max } .
$$

Indeed, when using the notation in Fig. 1, the input inductance of the equivalent circuit in Fig. $1, b$ is

$$
L=L_{1}=\left(n_{1} / n_{2}\right)^{2} L_{2}=n^{2} L_{2},
$$

and voltage-current relations for the elements are as follows:

$$
\begin{gathered}
v_{1} / v_{2}=n_{1} / n_{2}=n=N / N_{\max }, \\
i_{1} / i_{2}^{*}=-i_{1} / i_{L 2}=-n_{2} / n_{1}=-1 / n=-N_{\max } / N, \\
v_{2}=v_{L 2}=L_{2} \frac{d i_{L 2}}{d t}+i_{L 2} \frac{d L_{2}}{d t}
\end{gathered}
$$


where

$$
\frac{d i_{L 2}}{d t} \Rightarrow \frac{d}{d t}\left(n i_{1}\right)=n \frac{d i_{1}}{d t}+i_{1} \frac{d n}{d t}
$$

and

$$
\frac{d L_{2}}{d t}=N_{\max }^{2} \frac{d P}{d t}=\frac{d L_{2}}{d P} \frac{d P}{d t} .
$$

Therefore, from (23)-(28) we obtain

$$
\begin{aligned}
v_{L} & =v_{1}=n v_{2}=n\left(L_{2}\left(n \frac{d i_{1}}{d t}+i_{1} \frac{\Sigma^{-}}{d t}\right)+n i_{1} \frac{d L_{2}}{d t}\right)= \\
& =n^{2} L_{2} \frac{d i_{L}}{d t}+n i_{L} L_{2} \frac{d n}{d t}+n^{2} i_{L} N_{\max }^{2} \frac{d P}{d t}= \\
& =P N^{2} \frac{d i_{L_{2}}}{d t}+P N i_{L} \frac{d N_{c}}{d t}+N^{2} i_{L} \frac{d P}{d t},
\end{aligned}
$$

i.e. an expression identical with (9).

Taking into account that

$$
n i_{1} L_{2}=i_{L 2} L_{2}=\lambda_{L 2},
$$

the relation (29) can be rewritten in the form

$$
v_{L}=L \frac{d i_{L}}{d t}+\lambda_{L 2} \frac{d n}{d t}+n^{2} i_{L} \frac{d L_{2}}{d t}
$$

which sis suitable for writing the dual relation

$$
i_{C}=C \frac{d v_{C}}{d t}+q_{C 2} \frac{d n}{d t}+n^{2} v_{C} \frac{d C_{2}}{d t}
$$

for the conceivable capacitive one-port dual to the linear inductor with time-varying turns.

3.2. The dual capacitive one-port. To find the equivalent circuit of the capacitive one-port dual to the inductor with time-varying turns we may transform the equivalent circuit shown in Fig. 1,b into its dual. Firstly, the ideal transformer $T$ is replaced by its dual ideal transformer $T^{\prime}$, and the inductor $L_{2}$ - by the dual capacitor $C_{2}$. Secondly, the parallel connection of the inductor $L_{2}$ and the secondary winding of the transformer is replaced by the series connection of the capacitor $C_{2}$ and the secondary winding of the dual transformer. The result is shown in Fig. 2. The parallel (Fig. 1,b) and series (Fig. 2) connections of the two corresponding elements are stressed, using the common voltage and current, respectively.

To find the dual of the ideal transformer $T$ in Fig. 1,b, characterized by the relationships

$$
v_{1}=n v_{2}, \quad i_{1}=-i_{2} / n,
$$

Fig. 2. Linear capacitive one-port dual to the linear inductor with time-varying turns shown in Fig. 1.

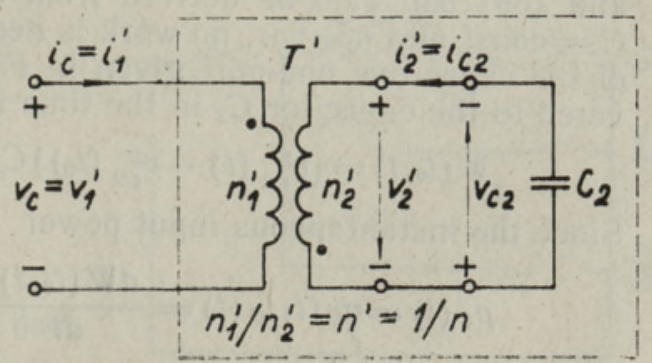


the corresponding dual relationships are found by replacing in (33) $v_{1}$ by $i_{1}^{\prime}, v_{2}$ by $i_{2}^{\prime}, i_{1}$ by $v_{1}^{\prime}$, and $i_{2}$ by $v_{2}^{\prime}$, which yields

$$
i_{1}^{\prime}=n i_{2}^{\prime}=i_{2}^{\prime} / n^{\prime}, \quad v_{1}^{\prime}=-v_{2}^{\prime} / n=-n^{\prime} v_{2}^{\prime} \text {. }
$$

According to (34) the dual of the ideal transformer is the same ideal transformer with its ports and the reference direction of one winding interchanged as shown in Fig. 2.

Using the notation in Fig. 2, the input capacitance of the equivalent circuit in Fig. 2 is

Since

$$
C=C_{1}=\left(n_{2}^{\prime} / n_{1}^{\prime}\right)^{2} C_{2}=n^{2} C_{2}
$$

$$
i_{2}^{\prime}=i_{C 2}=C_{2} \frac{d v_{C 2}}{d t}+v_{C 2} \frac{d C_{2}}{d t}
$$

and

$$
\begin{gathered}
v_{C 2}=-v_{2}^{\prime}=n v_{1}^{\prime}=n v_{C} \\
\frac{d v_{C 2}}{d t}=\frac{d}{d t}\left(n v_{C}\right)=n \frac{d v_{C}}{d t}+v_{C} \frac{d n}{d t}
\end{gathered}
$$

then from $(34)-(38)$ we obtain

$$
\begin{aligned}
i_{C} & =i_{1}^{\prime}=n i^{\prime}{ }_{2}=n\left(C_{2}\left(n \frac{d v_{C}}{d t}+v_{C} \frac{d n}{d t}\right)+n v_{C} \frac{d C_{2}}{d t}\right)= \\
& =n^{2} C_{2} \frac{d v_{C}}{d t}+v_{C 2} C_{2} \frac{d n}{d t}+n^{2} v_{C} \frac{d C_{2}}{d t}= \\
& =C \frac{d v_{C}}{d t}+q_{C 2} \frac{d n}{d t}+n^{2} v_{C} \frac{d C_{2}}{d t},
\end{aligned}
$$

i.e. an expression identical with (32) and dual to (31).

For the particular case of $C_{2}=$ const characterized by changing the input capacitance $C$ only due to the variation of turns ratio, we get

$$
\frac{d n}{d t}=\frac{d}{d t}\left(C / C_{2}\right)^{1 / 2}=\left(1 / 2 n C_{2}\right) \frac{d C}{d t} \text {. }
$$

Taking now into account that

$$
\frac{d C_{2}}{d t}=0 \quad \text { and } \quad q_{C 2}=C_{2} v_{C 2}=v_{C} C / n,
$$

we finally obtain from (39) and (40)

$$
i_{C}=C \frac{d v_{C}}{d t}+\frac{1}{2} v_{C} \frac{d C}{d t}
$$

i. e. the expression (4) given in the introduction on the basis of the duality principle.

As in the case of a time-varying inductor, the expressions (4), (32) and (39) can also be derived from the energy balance. For example, if $C_{2}=$ const and $n=$ var, no work is needed to change the input capacitance of the capacitive one-port given in Fig. 2. Consequently, the energy delivered to the capacitor $C_{2}$ in the time interval from $t_{0}$ to $t$, is

$$
W\left(t_{0}, t\right)=\left(v_{C 2}^{2}(t)-v_{C 2}^{2}\left(t_{0}\right)\right) C_{2} / 2=\left(v_{C}^{2}(t)-v_{C}^{2}\left(t_{0}\right)\right) C / 2 .
$$

Since the instantaneous input power

$$
p_{C}(t)=v_{C}(t) i_{C}(t)=\frac{d W\left(t_{0}, t\right)}{d t}=v_{C} C \frac{d v_{C}}{d t}+\frac{1}{2} v_{C}^{2} \frac{d C}{d t},
$$


we obtain

$$
i_{C}(t)=p_{C}(t) / v_{C}(t)=C \frac{d v_{C}}{d t}+\frac{1}{2} v_{C} \frac{d C}{d t},
$$

i. e. an expression identical with (4).

\section{Discussion}

The classical voltage-current relations (1) and (2) are used both for continuous and stepped variations of the parameter $\left[{ }^{1-4}\right]$. In case, of course, if the parameter varies due to the work done by the parameter changing agent, the stepped variation of the parameter is merely a useful idealization leading to the infinite rate of energy storage.

On the other hand, the variation of turns is, in principle, always the stepped one. Therefore, the relations (3), (4) and the rest related to one-ports with time-varying turns or turns ratio can give the exact result only in case the steps are taken into account. However, these relations can also be used as useful approximate design equations if a quasicontinuous variation of turns or turns ratio is assumed.

It is important to realize and useful to remember that in the case of constant flux $\Phi$ the voltage across an inductor is indentical to zero for all possible modes of the inductance variations. It follows immediately from the initial basic expression (8).

Another characteristic feature of the inductive and capacitive oneports with time-varying turns ratio is the stepped variation of the port flux linkage and the port charge. It results from the energy conservation law for the stepped variation of the port parameter when the stored energy remains unchanged.

To illustrate the phenomena stated above, let us consider a simple example of a short-circuited ideal inductor with time-varying turns and invariant permeance shown in Fig. 3.

Denote the initial current, turns, and inductance as follows:

$$
i_{L}(0)=I_{0}, \quad N(0)=N_{0}, \quad L(0)=L_{0} .
$$

Let us evaluate the time variations of the per unit turns $N_{\star}(t)=$ $=N(t) / N_{0}$ and per unit inductance $L_{*}(t)=L(t) / L_{0}$ in the case of sinusoidal modulation of the per unit current

$$
i^{\star}=i_{L}(t) / I_{0}=1+m \sin \omega t, \quad m<1
$$

by means of the turns variation.

First we shall consider the quasi-continuous variations of the turns and the inductance, using relation (3). Since in the case considered $v_{L}=0$, we get.

$$
L \frac{d i_{L}}{d t}+\frac{1}{2} i_{L} \frac{d L}{d t}=0
$$

and hence

Fig. 3. Short-circuited ideal inductor with timevarying (switched) turns.

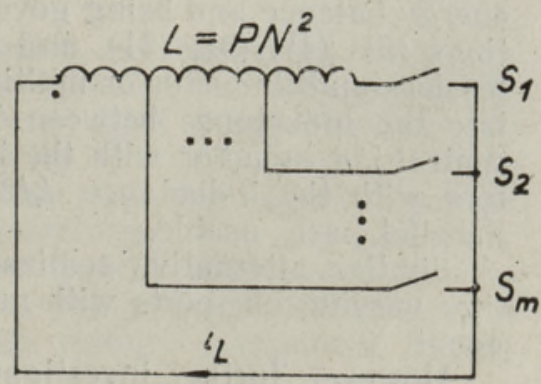




$$
\begin{gathered}
L i_{L} \frac{d i_{L}}{d t}+\frac{1}{2} i_{L}^{2} \frac{d L}{d t}=\frac{d}{d t} \frac{L i_{L}^{2}}{2}=\frac{d W_{L}}{d t}=0, \\
W_{L}=L i_{L}^{2} / 2=\text { const }=L_{0} I_{0}^{2} / 2,
\end{gathered}
$$

where $W_{L}$ - the energy stored in the magnetic field.

From (47) the time variations of the per unit inductance

$$
L_{*}=1 / i^{2}
$$

and, consequently, the per unit turns

$$
N_{*}=L_{*}^{1 / 2}=1 / i_{*}
$$

Since the stored energy $W_{L}$ can be expressed via the magnetic flux $\Phi$ and the magnetomotive force $F=N i_{L}$ in the form

$$
W_{L}=\Phi F / 2=P F^{2} / 2=\Phi^{2} / 2 P,
$$

it follows from (47) and (50) that in the case considered

$$
F=\text { const }=F_{0}, \quad \Phi=\text { const }=\Phi_{0} .
$$

Therefore, per unit flux linkage

$$
\lambda_{*}=N \Phi / N_{0} \Phi_{0}=N / N_{0}=N_{*} .
$$

The continuous time variations of $i_{*}, N_{*}=\lambda_{*}$; and $L_{*}$ are shown in Fig. 4 for $m=0.5$ (dashed lines).

Let us now consider the stepped variation of the current, turns, flux linkage and inductance, assuming that the sinusoidal alternating component of the current $i_{*}$ is approximated by the 12-pulse waveform shown in . Fig. 4 (solid line).

To evaluate the corresponding values of $N^{*}=\lambda^{*}$ and $L^{*}$, the same expressions (48) and (49) can be used. The resulting stepped variations of $N_{*}=\lambda_{*}$ and $L_{*}$ are plotted in Fig. 4 (solid lines).

The stepped variation of the inductor current by means of the turns switching is a fast operation, because it can be performed without any energy flow from the parameter changing agent. Therefore, the linear inductor with time-varying turns is a promising element to improve the waveshapes both of the alternating $\left[{ }^{6-18}\right]$ and direct $\left[{ }^{19-23}\right]$ currents in various static power converters.

On the basis of the duality, similar tasks can be performed also by the controlled lossless capacitive one-ports characterized by zero energy flow from the parameter changing agent.

As shown in this paper, the time-varying inductive and capacitive one-ports with no energy flow from the parameter changing agent can be realized by using turns or turns ratio variation. However, it is highly probable that, in addition, there exist other ways of realizing the inductive and capacitive time-varying one-ports having such a characteristic energy balance and being governed by the same new voltage-current relations (3), (4), (9); (31), and (32). For example, some types of switched, lossless multiinductor or multicapacitor circuits can be used. So, to modulate the inductance between the two levels $L$ and $L / 4$ both a single central-tap inductor with the total inductance $L$ and two separate inductors with the inductance $L / 2$ each switched alternately in series and parallel, are usable.

Similar alternative realizations are also possible for the capacitive time-varying one-ports with no energy flow from the parameter changing agent.

However, further investigation is needed to determine the total class 


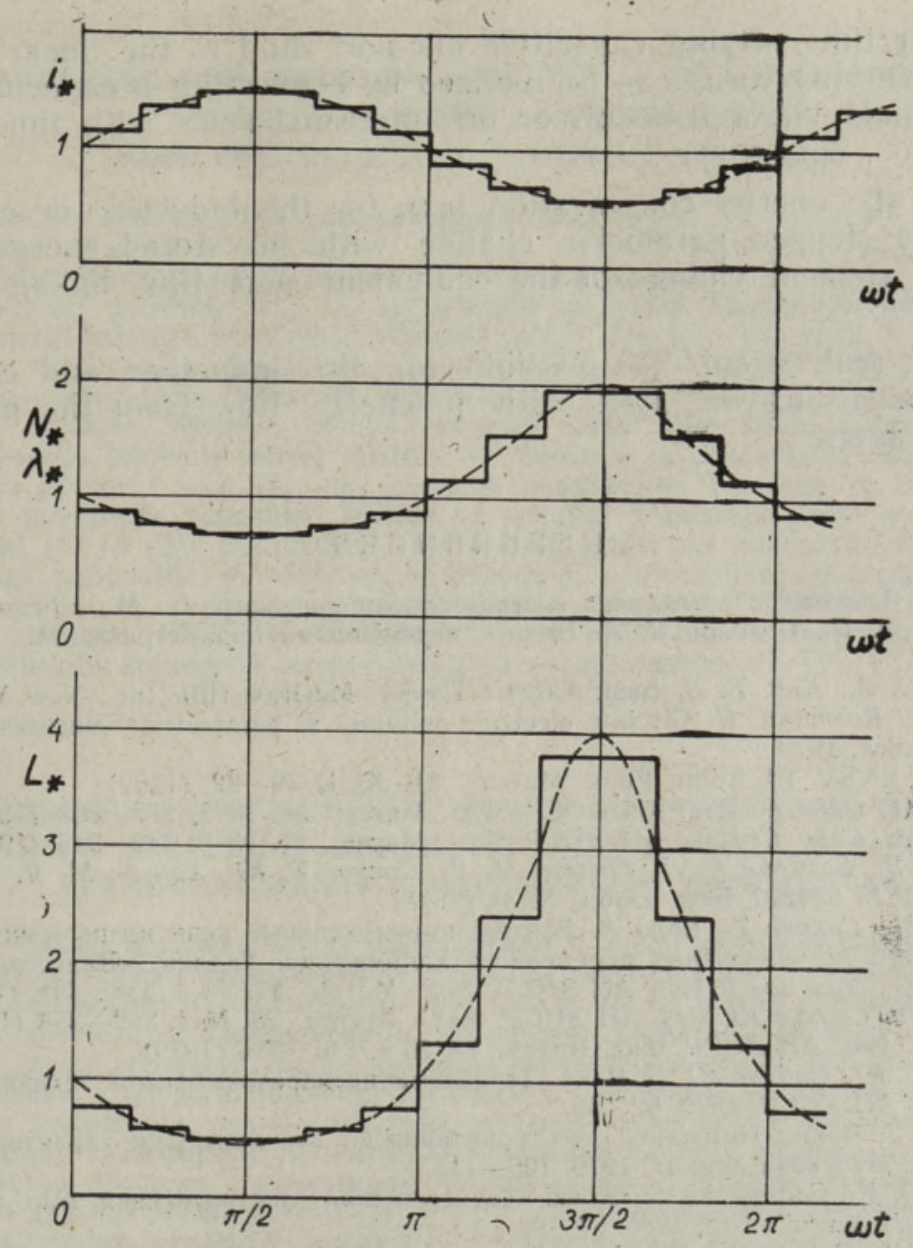

Fig. 4. Per unit current $i_{*}$, turns $N_{*}$, flux linkage $\lambda_{*}=N_{*}$ and inductance $L_{*}$ for the continuous (dashed lines) and stepped (solid lines) variations of the variables in the circuit Fig. 3.

of circuits governed by the relations derived in the paper, and moreover, circuits with the time-varying mutual inductance must be taken into account.

\section{Conclusions}

1. The voltage-current relations for linear inductive and capacitive oneports with a time-varying parameter depend on the energy flow from the parameter changing agent.

2. The inductance of a time-varying inductor can be varied, changing either the permeance or the turns of the inductor, or, simultaneously, both of them. From the viewpoint of the energy flow in the first case, the inductance changes due to the work done by the permeance changing agent, while no work and, therefore; no change in stored energy is needed to change the inductance via changing (switching) turns. Due to different modes of energy flow, the voltage component proportional to the rate of inductance change is twice smaller for a linear inductor with time-varying turns than the corresponding voltage component for an inductor with time-varying permeance. 
3. A linear time-varying capacitive one-port dual to the linear inductor with time-varying turns can be realized by connecting a capacitor to the port terminals via a transformer or autotransformer with time-varying turns ratio.

4. Due to the energy conservation law, for the inductive or capacitive one-ports a stepped parameter change with no stored energy change leads to a stepped change of the equivalent port flux linkage or port charge.

5. Various realizations are possible for the inductive and capacitive linear time-varying one-ports with no energy flow from the parameter changing agent.

\section{REFERENCES}

1. Тафт В. А. Электрические цепи с переменными параметрами. М., «Энергия», 1968.

2. Жарков Ф. П., Соколов В. А. Цепи с переменными параметрами. М., «Энергия», 1976.

3. Desoer, C. A., Kuh, E. S. Basic Circuit Theory. McGraw-Hill, Inc., New York, 1969.

4. Savin, C., Rosmann, H. Circuite electrice neliniare si parametrice. Bucuresti, Editura Technica, 1973.

5. Sarv, V. ENSV TA Toim. Füüs. Matem., 31, № 1, 79-82 (1982).

6. Оявеэр М., Сарв В. Изв. АН ЭССР. Физ. Матем., 26, № 3, 297-303 (1977).

7. Оявеэр М., Сарв В. Изв. АН ЭССР. Физ. Матем., 27, № 3, 342-348 (1978).

8. Сарв В. В., Батарин Г. Л., Оявеэр М. Р., Саккос Т. Ю., Хансен М. Я. Авт. свид. СССР № 624220. Бюл. изобр., № 34 (1978).

9. Оявеэр M., Саккос T., Сарв B. Вентильно-индуктивные цепи непрерывного амплитудного регулирования переменного напряжения. Таллин, «Валгус», 1978.

10. Сооярв Ю., Лаусмаа Т. Изв. АН ЭССР. Физ. Матем., 27, № 4, 438-444 (1978).

11. Каазик В.. Сооярв Ю. Изв. АН ЭССР. Физ. Матем., 28, № 4, 352-358 (1979).

12. Саћкос T. Изв. АН ЭССР. Физ. Матем., 28, № 4, 346-351 (1979).

13. Саккос Т. Ю., Сооярв Ю. Э. В кн.: Проблемы преобразовательной техники, I. Киев, ИЭД АН УССР, 1979, 62-65.

14. Сарв В. В. В кн.: Источники электропитания со специальными характеристиками. Киев, «Наукова думка», 1979, 106-113.

15. Каазик В. Т., Сооярв Ю. Э. В кн.: Теоретическая электротехника, вып. 28. Львов, Изд. Львовск. ун-та, 1980, 87-96.

16. Сарв В. В., Сооярв Ю. Э. Авт. свид. СССР № 857948. Бюл. изобр., № 31 (1981).

17. Оявеэр М. Р. В кн.: Уменьшение искажений в цепях с силовыми полупроводниковыми преобяазователями. Таллин, ИТЭФ АН ЭССР, 1981, 50-53.

18. Ojaveer. M., ENSV TA Toim. Füüs. Matem., 30, № 3, 260-267 (1981)

19. Сарв В. В., Сооярв Ю. Э. Авт. свид. СССР № 777782. Бюл. изобр.; № 41 (1980).

20. Сооярв Ю. Э. В кн.: Уменьшение искажений в цепях с силовыми полупроводниковыми преобразователями. Таллин, ИТЭФ АН ЭССР, 1981, 16-19.

21. Оявеэр М. Р., Сооярв Ю. Э. В кн.: Проблемы электромагнитной совместимости силовых полупроводниковых преобразователей, Таллин, ИТЭФ АН ЭССР, 1982, $253-254$

22. Сооярв Ю. Э., Сарв В. В., Тамкиви П. И. Авт. свид. СССР № 961066. Бюл. изобр., № 35 (1982).

23. Оявеэр М., Сооярв Ю. Изв. АН ЭССР. Физ. Матем., 32, № $161-65$ (1983).

Academy of Sciences of the Estonian SSR,

Institute of Thermophysics and Electrophysics

Received

May 26, 1983 


\section{SARV}

\section{LINEAARSE AJAS MUUTUVA INDUKTIIVSE JA MAHTUVUSLIKU KAKSKLEMMI PINGE JA VOOLU SEOSE NING ENERGIABILANSI VAHELINE SOLTUVUS}

On näidatud, et ajas muutuva induktiivsusega paispooli ja ajas muutuva mahtuvusega kondensaatori pinge ja voolu seosed sōltuvad oluliselt parameetrit muutva allikaga toimuvast energiavahetusest. Niisuguse paispooli induktiivsust saab muuta, muutes mag. netilist juhtivust, keerdude arvu vôi samaaegselt mõlemaid. Magnetilise juhtivuse muutmine on energiavahetuse seisukohalt võimalik ainult täiendava töö arvel, kuna aga keerdude arvu muutmiseks (ümberlülitamiseks) pole töö ideaaljuhul vajalik. Erinevate energiavahetusprotsesside tõttu on induktiivsuse muutumiskiirusega vōrdeline pingekomponent muutuva keerdude arvuga paispooli korral kaks korda väiksem kui muutuva magnetilise juhtivuse korral. Artiklis on tuletatud ja pōhjendatud uus üldine paispooli pinge ja voolu seos (9), mis arvestab magnetilise juhtivuse ja keerdude arvu samaaegse muutumise võimalust. Uhtlasi on esitatud duaalsusprintsiibi alusel vastavad uued seosed (4) ja (32) mahtuvusliku kaksklemmi jaoks, mis on duaalne muutuva keerdude arvuga paispoolile, ja näidatud, et niisuguse mahtuvusliku kaksklemmi realiseerimise üks võimalusi on kondensaatori ühendamine muutuva transíormatsiooniteguriga trafo või autotrafo väljundisse. Induktiivsuse ja mahtuvuse energiakuluta muutmise alusel on võimalik kujundada perspektiivseid filtreerimisskeeme.

\section{B. $C A P B$}

\section{ВЗАИМОСВЯЗЬ СООТНОШЕНИЯ МЕЖДУ НАПРЯЖЕНИЕМ И ТОКОМ И БАЛАНСА ЭНЕРГИИ В ЛИНЕИНЫХ ИНДУКТИВНОМ И ЕМКОСТНОМ ДВУХПОЛЮСНИКАХ С ПЕРЕМЕННЫМ ПАРАМЕТРОМ}

Показано, что соотношение между напряжением и током в параметрическом дросселе и конденсаторе зависит существенно от характера энергообмена с источником изменения параметра. Выведены и энергетически обоснованы новое общее соотношение (9) для линейного дросселя с одновременным изменением магнитной проводимости и числа витков, а также соответствующие дуальные соотношения (4) и (32) для емкостного двухполюсника, дуального линейному дросселю-с переменным числом витков. Показана возможная реализация такого емкостного двухполюсника путем соединения конденсатора к выходу трансформатора с переменным коэффициентом трансформации. Изменение параметра дросселя с переменным числом витков и соответствующего дуального емкостного двухполюсника не требует работы и поэтому является быстродействующим. Такие реактивные элементы являются перспективными при синтезе фильтрующих цепей. 